\title{
Оцінка емоційно-вольової сфери при розробці тренувального комплексу для універсальної моделі спортсмена з військово-авіаційного п'ятиборства (ВАП)
}

\author{
Андрій Полтавець' \\ Андрій Єфременко ${ }^{2}$ \\ Вячеслав Мулик \\ Андрій Кийко
}

Харківський національний університет Повітряних Сил імені Івана Кожедуба', Харків, Україна

Федерація сучасного п'ятиборства², Дармштадт, Німеччина

Харківська державна академія фізичної культури ${ }^{3}$ Харків, Україна

\begin{abstract}
Мета: проаналізувати вихідні показники, що характеризують тип темпераменту та лабільність нервової системи у курсантів першого курсу вищого навчального закладу, які є претендентами у збірну команду з міжнародного військово-авіаційного п'ятиборства.

Матеріал і методи: аналіз літературних джерел, тестування, статистичний аналіз. У дослідженні брали участь 48 курсантів першого курсу Харківського національного університету Повітряних Сил імені Івана Кожедуба (чоловіки) віком 17-18 років, з них 38 кандидатів у майстри спорту та 10 майстрів спорту.

Результати: враховуючи вихідні дані стосовно розподілу за видами спорту курсантів-чоловіків першого курсу ХНУПС, були визначені тип темпераменту та визначені дані лабільності нервової системи у курсантів першого курсу вищого навчального закладу, які є претендентами у збірну команду з міжнародного військово-авіаційного п'ятиборства. Було проведено аналіз отриманих даних у вигляді вербального опису, таблиць, аналітичного опису отриманих закономірностей.

Висновки: визначено, що вихідні показники типу темпераменту курсантів-претендентів у збірну команду з військово-авіаційного п'ятиборства, рівня самооцінки сили волі та властивостей нервової системи $\epsilon$ різнорідними. В змаганнях з військово-авіаційного п'ятиборства вирішальним $є 5$ день змагань - подолання смуги перешкод та спортивне орієнтування. Оскільки всі учасники команди повинні вирішувати одне й теж ідентичне завдання на фоні різних вихідних даних лабільності нервової системи та типу темпераменту, цей факт мотивує до пошуку тренувального методу, який би підтримував вже набуті досягнення і розвивав ті, які цього потребують, у рівній пропорції у всіх досліджуваних. Таким методом може слугувати метод кросфіту, що заснований на філософії багатостороннього фізичного розвитку і відповідає меті щодо розробки тренувального комплексу для підготовки спортсменів з військово-авіаційного п'ятиборства.
\end{abstract}

Ключові слова: військово-авіаційне п'ятиборство, темперамент, властивості нервової системи, лабільність нервової системи, кругове тренування, кросфіт.

\section{Вступ}

Відомо, що одним із найбільш складних за комплексом необхідних компетенцій, які повинен мати спортсмен з військово-авіаційного п'ятиборства (ВАП), є змагальний день проходження смуги перешкод разом із спортивним орієнтуванням.

Під час проходження смуги перешкод організм спортсмена зазнає функціональний стрес, що в більшості випадків при відсутності спеціальної попередньої підготовки може призвести до підвищення лабільності нервової системи, особливо емоційно-вольової сфери $[1,2]$.
Спортивне орієнтування є одним з найбільш специфічних видів спорту, у якому поєднуються високі фізичні і розумові навантаження на тлі великих вольових і емоційних напружень, спрямованих на самостійне вирішення низки практичних завдань [3, 4].

Через те що процес тренувань і змагань ставить перед спортсменами необхідність долати вкрай важкі, а в ряді випадків і безмежні психоемоційні і фізичні навантаження, особливо в змагальному періоді, і враховуючи той факт, що при відборі у збірну команду з ВАП курсанти-претенденти мають вік 17-18 років та сформований психотип особистості, мислення, відчуття і сприйняття і вже досягли високих результатів у спорті, але в різ- 
них його видах (ігрові, циклічні, складно-координаційні, спортивні єдиноборства) для формування комплексу тренувальних вправ, прийомів, методик важливим є дослідження у них типологічних особливостей темпераменту, властивостей нервової системи.

Враховуючи вищезазначене, важливим $є$ розвиток у спортсменів під час тренувань толерантності до емоційного стресу, який виникає на фоні функціонального стресу під час змагань з ВАП.

Тому метою дослідження було проаналізувати вихідні показники, що характеризують тип темпераменту та лабільність нервової системи у курсантів-претендентів у збірну команду з ВАП.

\section{Матеріал і методи дослідження}

У дослідженні брали участь 48 курсантів першого курсу Харківського національного університету Повітряних Сил імені Івана Кожедуба (чоловіки) віком 17-18 років, з них 38 кандидатів у майстри спорту та 10 майстрів спорту з різних видів спорту. Усі кандидати для подальшої тренувальної діяльності з військово-авіаційного п'ятиборства були розподілені на чотири групи за видами спорту, а саме: ігрові (група I - 12 курсантів), циклічні (група II - 14 курсантів), складно-координаційні (група III - 10 курсантів), спортивні єдиноборства (група IV - 12 курсантів). Курсанти, які брали участь у дослідженні, були рандомізовані за віком, антропометричними показниками та показниками загального здоров'я.

Для реалізації рандомізації було співставлено кожну із груп за показниками типу темпераменту за Г. Айзенком $[5,6]$ та самооцінки сили волі, що визначається за тестом М.М. Обозова $[7,8]$.

Оцінку властивостей нервової системи здійснювали за допомогою теппінг-тесту за Є.П. Ільїним [9, 10]. Перевагою методики теппінг-тесту Є.П. Ільїна $€$ те, що вона в психомоторній активності відображає насамперед зрушення в нервовій системі суб'єкта, а не в його м'язах. Тобто це різні механізми розвитку втоми, різні види втоми. Отже, ми не можемо робити висновки про силу нервової системи за витривалістю людини в роботі помірної чи великої інтенсивності. На ґрунті якісних кри- теріїв, які є головними, Є.П. Ільїн поділяє всіх досліджуваних на групи з сильною, середньою, середньо-слабкою і слабкою нервовою системою, саме ці характеристики ми використовували під час оцінки курсантів. Отже, для проведення оцінки стану показників вищої нервової діяльності на етапі формування збірної команди з ВАП серед курсантів першого курсу Харківського національного університету Повітряних Сил імені Івана Кожедуба ми визначали вищевказані показники на момент скринінгу досліджуваних.

Для обробки отриманих даних використовувалися методи параметричної статистики (Гланц С., 1999). Було проведено статистичну обробку даних, які були внесені в електронні таблиці Excel. Кількісні характеристики основних функціональних показників були оброблені статистично, а саме визначали середні арифметичні значення, похибку середньої. Перевірку значущості отриманих даних здійснювали за допомогою t-критерія Ст'юдента (для $n<100$ ) при заданому рівні надійності $\mathrm{p}=0,95$. Для можливості використання критерія Ст'юдента обчислювали критерій Фішера-Снедекора - відношення більшої дисперсії до меншої. Усі математичні операції і графічні побудови проведені з використанням програмних пакетів «Microsoft Office XP»: «Microsoft XP Home» і «Microsoft Excel XP» на персональному комп'ютері (номери ліцензій: 00049153 409442 та 74017640000010657664 відповідно).

\section{Результати дослідження}

При визначенні типу темпераменту, що є важливим показником при участі у змаганнях з ВАП, коли потрібно мінімізувати вплив суб'єктивних особливостей курсантів, були отримані результати (табл. 1).

При проведенні аналізу даних таблиці 1 було визначено, шо холериками-екстравертами з сильним, але неврівноваженим типом нервової системи, що характеризувало їх як нестабільну, збудливу, нестриману, агресивну, імпульсивну, оптимістичну, активну особистість з нестабільними працездатністю та настроєм і схильністю у ситуації стресу до істерико-психопатичних реакцій в групі I (ігрові види спорту) серед курсантів-претендентів у збірну команду з ВАП було 50\%, в групі II (циклічні види спорту) - 22\%, в гру-

Таблиця 1

Переважний тип темпераменту у курсантів першого курсу ХНУПС (чоловіки), претендентів у збірну команду з ВАП, за тестом Г. Айзенка, \%

\begin{tabular}{|l|c|c|c|c|}
\cline { 2 - 5 } \multicolumn{1}{c}{$\begin{array}{c}\text { Тип } \\
\text { темпераменту }\end{array}$} & $\begin{array}{c}\text { I (n=12)- ігрові } \\
\text { види спорту }\end{array}$ & $\begin{array}{c}\text { II (n=14)- } \\
\text { циклічні види } \\
\text { спорту }\end{array}$ & $\begin{array}{c}\text { III }(\mathrm{n}=10)- \\
\text { складно- } \\
\text { координаційні } \\
\text { види спорту }\end{array}$ & $\begin{array}{c}\text { IV (n=12)- } \\
\text { спортивні } \\
\text { єдиноборства }\end{array}$ \\
\hline Холерик & $6(50 \%)$ & $3(22 \%)$ & $3(30 \%)$ & $3(25 \%)$ \\
\hline Сангвінік & $3(25 \%)$ & $2(14 \%)$ & $4(40 \%)$ & $7(59 \%)$ \\
\hline Флегматик & $3(25 \%)$ & $9(64 \%)$ & $3(30 \%)$ & $2(16 \%)$ \\
\hline Меланхолік & 0 & 0 & 0 & 0 \\
\hline
\end{tabular}

Групи:

Група I - ігрові види спорту;

Група II - циклічні види спорту

Група III - складно-координаційні види спорту;

Група IV - спортивні одноборства 


\section{СЛОБОЖАНСЬКИЙ НАУКОВО-СПОРТИВНИЙ ВІСНИК}

пі III (складно-координаційні види спорту) - 30\%, в групі IV (спортивні єдиноборства) - 25\% спортсменів.

У свою чергу, сангвініками-екстравертами з сильним, врівноваженим, рухливим типом нервової системи, що характеризувало їх як стабільну, соціальну, спрямовану до зовнішнього світу, товариську особистість з впертістю відносно досягнення мети в групі I були 25\%, в групі II - 14\%, в групі III - 40\%, в групі IV - 59\% спортсменів.

Флегматиками-інтровертами з сильним, врівноваженим, проте інертним типом нервової системи, що характеризувало їх як стабільну, повільну, спокійну, пасивну, незворушну, обережну, замислену, стриману, надійну, спокійну у взаєминах, здатну витримати тривалі негаразди без зривів здоров'я і настрою особистість, в групі I були 25\%, в групі II - 64\%, в групі III - 30\%, в групі IV - 16\% курсантів. При цьому серед досліджуваних в жодному разі не було визначено темпераменту, який би відповідав характеристиці меланхоліків-інтровертів із слабкою нервовою системою.

Отже, можна відзначити, що, незважаючи на переважну кількість того або іншого типу темпераменту в кожній із груп, що, безперечно, мало взаємодію з видом спортивної діяльності, у якій курсанти мали значущі на момент проведення дослідження спортивні досягнення (KMC, MC), в цілому в кожній із категорій спортивної діяльності були курсанти з різними типами нервової системи, які вже склалися на момент вступу до університету і характеризували їх індивідуальну особистість.

Слід відзначити, що, враховуючи принципові відмінності кожного змагального дня з ВАП, кожен із спортсменів мав перевагу в тому або іншому спортивному конкурсі, що сприяло врівноваженості загальної кількості балів на момент останнього дня - подолання смуги пе- решкод та спортивного орієнтування. Враховуючи, що вплинути на тип темпераменту та функціональний стан нервової системи у курсанта під час підготовки до змагань не є можливим з огляду на вік, попередній досвід та сформовану особистість, важливим $€$ розробка та втілення в тренувальний процес комплекс методів, які б розвивали якості, які можна отримати при фізичному та розумовому навантаженні.

При визначенні рівня самооцінки сили волі за тестом М.М. Обозова (таблиця 2) були визначено, що слабку силу волі не мав жоден з курсантів, які брали участь у дослідженні, що й є логічним за умов наявності в кожного з них високих спортивних досягнень на момент проведення дослідження.

Рівень самооцінки сили волі (суб'єктивний критерій, але інформаційно важливий для побудови тренувального процесу), який визначався як середній, в групі I був визначений у $50 \%$ курсантів $(15,1 \pm 0,9$ балів), в групі II

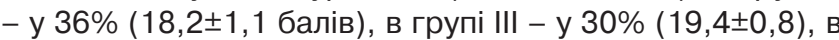
групі IV - у 42\% спортсменів (19,2ะ1,1 балів). При цьому найнижчі його значення були у досліджуваних, які мали досягнення з ігрових видів спорту, що було вірогідно $(p<0,05)$ меншим, ніж кількість балів в групах II, III та IV, що, ймовірно, залежало від зменшення відповідальності на особистому рівні при участі у командних (ігрових) змаганнях. В групах II, III та IV кількість балів, що характеризувала рівень самооцінки сили волі, майже відрізнялася і відповідала верхній межі діапазону значень.

Рівень самооцінки сили волі, який визначався як високий (сила волі велика), в групі I був визначений у 50\% курсантів $(24,6 \pm 0,7$ балів), в групі II - у 64\% $(25,1 \pm 1,2$ балів), в групі III - у 70\% $(27,2 \pm 1,4)$, в групі IV - у 58\% спортсменів $(24,9 \pm 1,2)$ балів. При цьому найнижчі його

Таблиця 2

Показник рівня самооцінки сили волі у курсантів першого курсу ХНУПС (чоловіки), претендентів у збірну команду з ВАП, за тестом М.М. Обозова, $\bar{x}+m$, бали

\begin{tabular}{|c|c|c|c|c|}
\hline \multirow{2}{*}{$\begin{array}{c}\text { Рівень самооцінки } \\
\text { сили волі }\end{array}$} & \multicolumn{4}{|c|}{ Групи } \\
\hline & $\mathrm{I}(\mathrm{n}=12)$ & II $(n=14)$ & III $(n=10)$ & IV $(n=12)$ \\
\hline $\begin{array}{l}\text { Від } 0 \text { до } 12 \text { балів - } \\
\text { слабка сила волі }\end{array}$ & 0 & 0 & 0 & 0 \\
\hline $\begin{array}{l}\text { Від } 13 \text { до } 21 \text { балів - } \\
\text { сила волі середня }\end{array}$ & $\begin{array}{l}6(50 \%) \\
15,1 \pm 0,9\end{array}$ & $\begin{array}{l}5(36 \%) \\
18,2 \pm 1,1\end{array}$ & $\begin{array}{l}3(30 \%) \\
19,4 \pm 0,8\end{array}$ & $\begin{array}{l}5(42 \%) \\
19,2 \pm 1,1 \\
\end{array}$ \\
\hline $\begin{array}{l}\text { Сила волі середня, } \\
\text { бали }\end{array}$ & \multicolumn{4}{|c|}{$\begin{array}{r}\mathbf{t}_{1,2}=\mathbf{2 , 7 0}\left(\mathbf{p}_{\mathbf{2 , 4}}<\mathbf{0 , 0 5}\right) ; \mathbf{t}_{1,3}=\mathbf{3 , 2 2}\left(\mathbf{p}_{\mathbf{1 , 3}}<\mathbf{0 , 0 5}\right) ; \\
\mathbf{t}_{1, \mathbf{4}}=\mathbf{2 , 2 1}\left(\mathbf{p}_{\mathbf{1}, \mathbf{4}}<\mathbf{0 , 0 5}\right) ; \mathrm{t}_{2,3}=1,34\left(\mathrm{p}_{2,3}>0,05\right) ; \\
\mathrm{t}_{2,4}=1,41\left(\mathrm{p}_{2,4}>0,05\right) ; \mathrm{t}_{3,4}=0,59\left(\mathrm{p}_{3,4}>0,05\right)\end{array}$} \\
\hline $\begin{array}{l}\text { Від } 22 \text { до } 30 \text { балів - } \\
\text { велика сила волі }\end{array}$ & $\begin{array}{l}6(50 \%) \\
24,6 \pm 0,7\end{array}$ & $\begin{array}{l}9(64 \%) \\
25,1 \pm 1,2\end{array}$ & $\begin{array}{l}7(70 \%) \\
27,2 \pm 1,4\end{array}$ & $\begin{array}{l}7(58 \%) \\
24,9 \pm 1,2 \\
\end{array}$ \\
\hline $\begin{array}{l}\text { Сила волі велика, } \\
\text { бали }\end{array}$ & \multicolumn{4}{|c|}{$\begin{aligned} & \mathrm{t}_{1,2}=1,55\left(\mathrm{p}_{1,2}>0,05\right) ; \mathbf{t}_{1,3}=\mathbf{2 , 4 8}\left(\mathbf{p}_{1,3}<\mathbf{0 , 0 5}\right) ; \\
& \mathrm{t}_{1,4}=1,60\left(\mathrm{p}_{1,4}>0,05\right) ; \mathrm{t}_{2,3}=1,37\left(\mathrm{p}_{2,3}>0,05\right) ; \\
& \mathrm{t}_{2,4}=1,47\left(\mathrm{p}_{2,4}>0,05\right) ; \mathrm{t}_{3,4}=0,54\left(\mathrm{p}_{3,4}>0,05\right)\end{aligned}$} \\
\hline
\end{tabular}

Групи:

Група I - ігрові види спорту;

Група II - циклічні види спорту

Група III - складно-координаційні види спорту;

Група IV - спортивні одноборства

Полтавець, А., Єфременко, А., Мулик, В., Кийко, А. (2020), «Оцінка емоційно-вольової сфери при розробці тренувального комплексу для універсальної моделі спортсмена з військово-авіаційного п'ятиборства (ВАП)»
Слобожанський науково-спортивний вісник, № 6(80), С. 32-38, doi:10.15391/snsv.2020-6.005 
значення були у досліджуваних, які мали досягнення з ігрових видів спорту, що було вірогідно $(p<0,05)$ меншим, ніж кількість балів в групі III. Найбільша кількість балів була за даним показником визначена у курсантів, які займалися складно-координаційними видами спорту і мали високі спортивні досягнення.

Важливим також $є$ показник однорідності рівня самооцінки сили волі в кожній із груп. Так, найменш однорідним цей показник був в групах I та III, однак в групі I 50\% курсантів мали самі низькі значення рівня самооцінки сили волі серед усього контингенту досліджуваних. Навпаки, в групі III високу оцінку мали 70\% спортсменів з максимальними значеннями серед усіх досліджуваних курсантів. У групах II і III даний показник був найбільш однорідним, але переважна кількість спортсменів мали високий рівень самооцінки сили волі 64\% і 58\% відповідно.

При визначенні властивостей нервової системи за допомогою теппінг-тесту за Є.П. Ільїним (таблиця 3), підраховувалась кількість точок в кожному квадраті, після чого будували діаграму працездатності для кожного курсанта окремо шляхом відкладання на осі абсцис 5-секундних інтервалів часу, а на осі ординат - кількість точок в кожному квадраті. Важливим моментом при інтерпретації даних було розуміння, що сила нервових процесів $є$ показником працездатності нервових клітин і нервової системи в цілому. Сильна нервова система витримує велике за величиною і тривалістю навантаження, ніж слабка.

Отримані нами дані щодо властивостей нервової системи у всіх досліджуваних визначили неоднорідність, відсоток якої співпадав у кожній із груп, незважаючи на наявність спортивного результату за одним видом діяльності. Так, у групі І, опуклий тип кривої, що характеризує сильну нервову систему, був визначений у 33\% курсантів, рівний тип - нервова система середньої сили - у 33\%, і низхідний тип - слабка нервова сис- тема - також у 33\% спортсменів. У групі II опуклий тип кривої діаграми, рівний їі тип були отримані у 50\% та 30\% курсантів відповідно, при цьому у жодного з них не було отримано висхідного типу кривої, а у останніх $20 \%$ визначався ії проміжний тип, що відповідав середньослабкій нервовій системі.

В групі III опуклий, рівний та проміжний тип кривої були отримані при побудові індивідуальних діаграм у 60\%, 30\% та 10\% відповідно. При цьому в групі IV співвідношення щодо типу нервової системи серед спортсменів співпадало з результатами, отриманими при проведенні аналізу даних в групі I і складало 33\%, $33 \%$ та $33 \%$ опуклий, рівний та низхідний тип кривої відповідно.

Враховуючи отримані дані, можна відзначити, що вихідні показники типу темпераменту курсантів-претендентів у збірну команду з ВАП, рівня самооцінки сили волі та властивостей нервової системи $є$ різнорідними. Враховуючи перші 4 дні спортивного конкурсу з ВАП, присвячені різним за своєю ідеологією видам змагань - стрільба з пневматичного пістолету, плавання, фехтування та баскетбол - наявність неоднорідності показників за проведеними тестами сприяє, навпаки, однорідності отриманих командних балів, які визначаються як середнє на всіх учасників. При цьому важливим $є$ вирішальний, 5 день змагань - подолання смуги перешкод та спортивне орієнтування, так як всі учасники команди повинні вирішувати одне й теж, ідентичне завдання на фоні різних вихідних даних. Це мотивує до пошуку тренувального методу, який би підтримував вже набуті досягнення і розвивав ті, які цього потребують, в рівній пропорції у всіх досліджуваних. Отже саме метод кросфіту, що заснований на філософії багатостороннього фізичного розвитку, $€$ максимально тим, що відповідає меті щодо розробки тренувального комплексу спортсменів з ВАП.

Таблиця 3

Показник властивостей нервової системи у курсантів першого курсу ХНУПС (чоловіки), претендентів у збірну команду з ВАП, за допомогою теппінг-тесту за Є.П. Ільїним, \%

\begin{tabular}{|l|c|c|c|c|}
\hline \multirow{2}{*}{ Тип нервової системи } & \multicolumn{4}{|c|}{ Групи } \\
\cline { 2 - 5 } & I (n=12) & II (n=14) & III (n=10) & IV (n=12) \\
\hline $\begin{array}{l}\text { Опуклий тип кривої, сильна } \\
\text { нервова система }\end{array}$ & $4(33 \%)$ & $7(50 \%)$ & $6(60 \%)$ & $4(33 \%)$ \\
\hline $\begin{array}{l}\text { Рівний тип кривої, нервова } \\
\text { система середньої сили }\end{array}$ & $4(33 \%)$ & $4(30 \%)$ & $3(30 \%)$ & $4(33 \%)$ \\
\hline $\begin{array}{l}\text { Низхідний тип кривої, слабка } \\
\text { нервова система }\end{array}$ & $4(33 \%)$ & 0 & 0 & $4(33 \%)$ \\
\hline $\begin{array}{l}\text { Проміжний тип кривої, середньо- } \\
\text { слабка нервова система }\end{array}$ & 0 & $3(20 \%)$ & $1(1 \%)$ & 0 \\
\hline $\begin{array}{l}\text { Увігнутий тип кривої, середньо- } \\
\text { слабка нервова система }\end{array}$ & 0 & 0 & 0 & 0 \\
\hline
\end{tabular}

Групи:

Група I - ігрові види спорту;

Група II - циклічні види спорту

Група III - складно-координаційні види спорту;

Група IV - спортивні одноборства 


\section{СЛОБОЖАНСЬКИЙ НАУКОВО-СПОРТИВНИЙ ВІСНИК}

\section{Висновки / Дискусія}

Введення під час процесу відбору спортсменів у збірну команду з міжнародного військово-авіаційного п'ятиборства тестування з визначення типу темпераменту, рівня самооцінки сили волі та сили нервової системи є важливим моментом у визначенні відповідного алгоритму подальшого тренування.

При визначенні властивостей нервової системи за допомогою теппінг-тесту за Є.П. Ільїним, та інтерпретації даних було важливим моментом розуміння, що сила нервових процесів є показником працездатності нервових клітин і нервової системи в цілому. Сильна нервова система витримує велику за величиною і тривалістю навантаження, ніж слабка.

При проведенні аналізу даних, отриманих при визначені типу нервової системи, у кожного із спортсменів ми вносили в таблиці кількість досліджуваних, у яких діаграми визначали той або інший тип нервової системи. Враховуючи, що всі курсанти на момент рандомізації мали значущі спортивні досягнення (КМС, МС), метою визначення властивостей нервової системи за теппінгтестом було розуміння вихідних даних щодо форми урівноваження організму спортсменів із зовнішнім середовищем. Через те що успішність оволодіння і реалізація спортивних амбіцій залежить від того, чи відповідає діяльність або її стиль виконання вихідному психофізичному статусу, отримання різних, неоднорідних результатів $€$ мотивацією щодо пошуку оптимальних психофізичних шляхів побудови тренувального процесу, спрямованих на досягання успіху в одному виді діяльності (спортивний конкурс з ВАП) курсантів з різними типологічними особливостями.

При співставленні даних, отриманих при визначенні темпераменту досліджуваних, типу лабільності їх нервової системи, а також рівня самооцінки сили волі, необхідно відзначити, що показники є неоднорідними. Ті або інші особливості кожного із спортсменів додають єдине ціле у кількість балів за перші 4 змагальних дні, так як кожна складова спортивного конкурсу з ВАП передбачає для учасників проходження етапів з різними диференційованими спортивними завданнями. Таким чином, важливим $€$ тренування працездатності, витривалості, рухово-координаційних якостей та когнітивних можливостей, які б сприяли зібранню максимальної кількості балів саме у останній змагальний день при подоланні смуги перешкод та виконанні завдання зі спортивного орієнтування.

Заняття протягом тривалого часу тим або іншим (ігрові, циклічні, складно-координаційні, єдиноборства) видом спорту напередодні до статусу претендента на членство у збірну команду з ВАП робить необхідним розробку універсального комплексу фізичних вправ, виконання яких не вимагає спеціального обладнання, є зрозумілим, і відповідає вимогам, що за певну кількість повторювань різнонаправлених вправ майстерність можна формувати прискоренням їх виконання та збільшенням їх кількості в залежності від фази тренувального процесу з досяганням піку можливостей безпосередньо перед змаганнями.

Конфлікт інтересів. Автори заявляють, що відсутній конфлікт інтересів, який може сприйматись таким, що може завдати шкоди неупередженості статті.

Джерела фінансування. Ця стаття не отримала фінансової підтримки від державної, громадської або комерційної організації.

\section{Список посилань}

1. Кирпенко В. М., Золочевський В. В., Полтавець А. І. (2020), Подолання перешкод. Смуга перешкод СISM, ХHУПС ім.І.Кожедуба, Харків, 104 с.

2. Кирпенко В. М., Піддубний О. Г., Полтавець А. І. (2016), Аеронавтичне багатоборство, ХНУПС ім.І.Кожедуба, Харків, 168 с.

3. Щербаков М. А, Лянной М. О. (2015), Основи спортивного орієнтування : навчально-методичні рекомендації, Суми: Вид-во СумдПУ імені А. С. Макаренка, 32 с.

4. Ланда Б. Х. (2011), Методика комплексной оценки физического развития и физической подготовленности, Москва: Советский спорт, 348 с.

5. Райгородский Д. Я (2006), Практическая психодиагностика. Методики и тесты, Санкт-Петербург: Бахрах-М, 672 с.

6. Юнг К. Г. (2017), Психологические типы, Москва: Академический проект, 540 с.

7. Ильин Е. П. (2009), Психология воли, Санкт-Петербург: Питер, 368 с.

8. Карелин А. А. (2007), Большая энциклопедия психологических тестов, Москва: Эксмо, 416 с.

9. Ильин Е. П. (2019), Психология спорта, Санкт-Петербург: Питер, 352 с.

10. Ильин Е. П., Семенов М. С. (1972), Психофизиологические основы физического воспитания и спорта, Ленинград: Ленинградский государственный педагогический институт им. А. И. Герцена, 186 с.

Стаття надійшла до редакції: 25.11.2020 p.

Опубліковано: 21.12.2020 р. 


\section{СЛОБОЖАНСЬКИЙ НАУКОВО-СПОРТИВНИЙ ВІСНИК}

Аннотация. Андрей Полтавец, Андрей Ефременко, Вячеслав Мулик, Андрей Кийко. Оценка эмоциональноволевой сферы при разработке тренировочного комплекса для универсальной модели спортсменов военно-авиационного пятиборья (ВАП). Цель: проанализировать исходные показатели, характеризующие тип темперамента и лабильность нервной системы, у курсантов первого курса высшего учебного заведения, которые являются претендентами в сборную команду по международному военно-авиационного пятиборью. Материал и методы: анализ литературных источников, тестирование, статистический анализ. В исследовании принимали участие 48 курсантов первого курса Харьковского национального университета Воздушных Сил имени Ивана Кожедуба (мужчины) в возрасте 17-18 лет, из них 38 кандидатов в мастера спорта и 10 мастеров спорта. Результаты: учитывая исходные данные о распределении по видам спорта курсантов-мужчин первого курса ХНУПС, были определены тип темперамента и определенные данные лабильности нервной системы у курсантов первого курса высшего учебного заведения, которые являются претендентами в сборную команду по международному военно-авиационному пятиборью. Был проведен анализ полученных данных в виде вербального описания, таблиц, аналитического описания полученных закономерностей. Выводы: определено, что исходные показатели типа темперамента уровня самооценки силь воли и свойств нервной системы курсантов-претендентов в сборную команду по военно-авиационному пятиборью являются неоднородными. В соревнованиях по военно-авиационному пятиборью решающим является 5 день соревнований - преодоление полосы препятствий и спортивное ориентирование. Так как все участники команды должны решать одно и то же, идентичное задание на фоне различных исходных данных лабильности нервной системы и типа темперамента, этот факт мотивирует к поиску тренировочного метода, который бы поддерживал уже приобретенные достижения и развивал те, которые в этом нуждаются в равной пропорции во всех исследуемых. Таким методом может служить метод кроссфита, основанный на философии многостороннего физического развития и соответствующий цели по разработке тренировочного комплекса для подготовки спортсменов по ВАП.

Ключевые слова: военно-авиационное пятиборье, темперамент, свойства нервной системы, лабильность нервной системы, круговая тренировка, кроссфит.

Abstract. Andriy Poltavets, Andriy Efremenko, Viacheslav Mulyk, Andriy Kyyko. Evaluation of the emotional-volitional sphere in the development of a training complex for a universal model of athletes in the military aviation pentathlon. Purpose: to analyze the initial indicators characterizing the type of temperament and lability of the nervous system in first-year cadets of a higher educational institution who are applicants for the national team in international military -aviation pentathlon. Material and methods: analysis of literature sources, testing, statistical analysis. The study involved 48 first-year cadets of the Kharkiv National University of the Air Force named after Ivan Kozhedub (men) aged 17-18, of whom 38 candidates for Master of Sports and 10 Masters of Sports. Results: taking into account the initial data on the distribution of male cadets of the first year of the KhNUPS by sport, the type of temperament and certain data on the lability of the nervous system in the first year cadets of a higher educational institution were determined, they are applicants for the national team in the international military aviation pentathlon. The analysis of the data obtained was carried out in the form of a verbal description, tables, an analytical description of the obtained patterns. Conclusions: it was determined that the initial indicators of the type of temperament, the level of self-assessment of willpower and the properties of the nervous system of cadetsapplicants for the combined team in military aviation pentathlon are non-uniform. In competitions in military aviation pentathlon, the decisive day is the 5th day of the competition - overcoming the obstacle course and orienteering. Since all team members must solve the same, identical task against the background of different initial data on the lability of the nervous system and the type of temperament, this fact motivates the search for a training method that would support the achievements already acquired and develop those who need it equal proportion in all subjects. This method can be a crossfit method based on the philosophy of versatile physical development and meets the goal of developing a training complex for training athletes according.

Keywords: military aviation pentathlon, temperament, properties of the nervous system, lability of the nervous system, circuit training, crossfit.

\section{References}

1. Kirpenko, V. M., Zolochevskii, V. V. and Poltavets, A. I. (2020), Podolannya pereshkod. Smuga pereshkod CISM [Overcoming obstacles. CISM obstacle course], KhNUPS im.I.Kozheduba, Kharkiv, 104 p. (in Ukr)

2. Kirpenko, V. M., Piddubnii, O. G. and Poltavets, A. I. (2016), Aeronavtichne bagatoborstvo [Aeronautical all-around], KhNUPS im.I.Kozheduba, Kharkiv, 168 p. (in Ukr)

3. Shcherbakov, M. A, Lyannoy, M. O. (2015), Fundamentals of sports orientation [Basics of orienteering]: educational and methodical recommendations, Sumy: Publishing house of Sumy State Pedagogical University named after AS Makarenko, 32 p. (in Ukr).

4. Landa, B.Kh. (2011), Metodika kompleksnoi otsenki fizicheskogo razvitiya i fizicheskoi podgotovlennosti [Methodology for a comprehensive assessment of physical development and physical fitness], Moskva: Sovetskii sport, 348 p. (in Russ.)

5. Raygorodskiy, D. Ya (2006), Prakticheskaya psihodiagnostika. Metodiki i testy [Practical psychodiagnostics. Techniques and tests], Sankt-Peterburg: Bahrah-M, 672 p. (in Russ.)

6. Yung, K. G. (2017), Psihologicheskie tipy [Psychological types], Moskva: Akademicheskiy proekt, 540 p. (in Russ.)

7. Ilin, E. P. (2009), Psihologiya voli [The psychology of will], Sankt-Peterburg: Piter, 368 p. (in Russ.)

8. Karelin, A. A. (2007), Bolshaya entsiklopediya psihologicheskih testov [Great encyclopedia of psychological tests], Moskva: Eksmo, 416 p. (in Russ.)

9. Ilin, E. P. (2019), Psihologiya sporta [Sports psychology], Sankt-Peterburg: Piter, 352 p. (in Russ.)

10. Ilin, E. P., Semenov, M. S. (1972), Psihofiziologicheskie osnovyi fizicheskogo vospitaniya i sporta [Psychophysiological foundations of physical education and sports], Leningrad: Leningradskiy gosudarstvennyiy pedagogicheskiy institut im. A. I. Gertsena, 186 p. (in Russ.)

Received: 25.11.2020.

Published: 21.12 .2020 .

Полтавець, А., Єфременко, А., Мулик, В., Кийко, А. (2020), «Оцінка емоційно-вольової сфери при розробці тренувального комплексу для універсальної моделі спортсмена з військово-авіаційного п'ятиборства (ВАП)»"
Слобожанський науково-спортивний вісник, № 6(80), С. 32-38, doi:10.15391/snsv.2020-6.005 


\section{СЛОБОЖАНСЬКИЙ НАУКОВО-СПОРТИВНИЙ ВІСНИК}

\section{Відомості про авторів / Information about the Authors}

Полтавець Андрій Іванович: Харківський національний університет Повітряних Сил імені Івана Кожедуба: вул. Сумська 77/79, м. Харків, 61058, Україна.

Полтавец Андрей Иванович: Харьковский национальный университет Воздушних Сил имени Ивана Кожедуба: ул. Сумская 77/79, г. Харьков, 61058, Украина.

Andriy Poltavets: Ivan Kozhedub Kharkiv National Air Force University: Klochkivska str. 99, Kharkiv, 61058,Ukraine.

ORCID.ORG/0000-0003-0695-4465

E-mail: apoltavec82@gmail.com

Єфременко Андрій: к.фіз.вих., головний тренер національної юніорської збірної команди Німеччини з сучасного п'ятиборства; Федерація сучасного п'ятиборства Німеччини: Юліус-Рейбер-Стріт 5, Дармштадт, 64293, Німеччина.

Ефременко Андрей: к.физ.восп., главный тренер юниорской сборной Германии по современному пятиборью; Федерация современного пятиборья Германии: Юлиус-Рейбер-Стрит 5, Дармштадт, 64293, Германия.

Andriy Efremenko: PhD (Physical Education and Sport), Head coach of Germany National Junior team; German Federation of Modern Pentathion: Julius-Reiber-Str. 5, Darmstadt, 64293, Germany

ORCID.ORG/0000-0001-7185-7595

E-mail: rigocepega@gmail.com

Мулик Вячеслав Володимирович: д. Фіз.вих., професор; Харківська державна академія фізичної культури: вул. Клочківська 99, м. Харків, 61058, Україна.

Мулик Вячеслав Владимирович: д. физ.восп., професор; Харьковская государственная академия физической культуры: ул. Клочковская 99, г. Харьков, 61058, Украина.

Viacheslav Mulyk: Doctor of Science (Physical Education and Srort), Prof., Kharkiv State Academy of Physical Culture: Klochkivska str. 99, Kharkiv, 61058,Ukraine.

ORCID.ORG/0000-0002-4441-1253

E-mail: mulyk.viacheslav@gmail.com

Кийко Андрій Сергійович: к.фіз.вих.; Харківська державна академія фізичної культури: вул. Клочківська 99, м. Харків, 61058, Україна.

Кийко Андрей Сергеевич: к.физ.восп.; Харьковская государственная академия физической культуры: ул. Клочковская 99, г. Харьков, 61058, Украина.

Andriy Kyyko: PhD (Physical Education and Sport); Kharkiv State Academy of Physical Culture: Klochkivska str. 99, Kharkiv, 61058,Ukraine.

ORCID.ORG/0000-0002-6248-3576

E-mail: kiyko8000@gmail.com 